\title{
Strengthening understanding and perceptions of mineral fertilizer use among smallholder farmers: evidence from collective trials in western Kenya
}

\author{
Michael Misiko • Pablo Tittonell • Ken E. Giller • \\ Paul Richards
}

Accepted: 29 August 2009/Published online: 20 March 2010

(C) The Author(s) 2010. This article is published with open access at Springerlink.com

\begin{abstract}
It is widely recognized that mineral fertilizers must play an important part in improving agricultural productivity in western Kenyan farming systems. This paper suggests that for this goal to be realized, farmers' knowledge must be strengthened to improve their understanding of fertilizers and their use. We analyzed smallholder knowledge of fertilizers and nutrient management, and draw practical lessons from empirical collective fertilizer-response experiments. Data were gathered from the collective fertilizer-response trials, through focus group discussions, by participant observation, and via in-depth interviews representing 40 households. The collective trials showed that the application of nitrogen $(\mathrm{N})$ or phosphorous (P) alone was insufficient to enhance yields in the study area. The response to $\mathrm{P}$ on the trial plots was mainly influenced by incidences of the parasitic Striga weed, by spatial variability or gradients in soil fertility of the experimental plots, and by interactions with $\mathrm{N}$ levels. These results inspired farmer to design and conduct
\end{abstract}

M. Misiko ( $\square)$

Learning and Innovation Systems, Africa Rice Centre

(AfricaRice), 01 BP 2031, Cotonou, Benin

e-mail:m.misiko@cgiar.org

P. Tittonell

Unité de Recherche Systèmes de Culture Annuels,

CIRAD-Persyst, TA B 102/02 Avenue Agropolis,

34398 Montpellier Cedex 5, France

K. E. Giller

Plant Production Systems (PPS), Wageningen University,

Postbus 430, 6700 AK Wageningen, The Netherlands

P. Richards

Technology and Agrarian Development (TAD), Wageningen

University, Postbus 8130, 6700 EW Wageningen,

The Netherlands experiments to compare crop performance with and without fertilizer, and between types of fertilizers, or responses on different soils. Participating farmers were able to differentiate types of fertilizer, and understood rates of application and the roles of respective fertilizers in nutrient supply. However, notions were broadly generated by unsteady yield responses when fertilizers were used across different fertility gradients, association with high cost (especially if recommended rates were to be applied), association of fertilizer use with hybrids and certain crops, historical factors, among other main aspects. We identified that strengthening fertilizer knowledge must be tailored within existing, albeit imperfect, systems of crop and animal husbandry. Farmers' perceptions cannot be changed by promoting more fertilizer use alone, but may require a more basic approach that, for example, encourages farmer experimentation and practices to enhance soil properties such as carbon build-up in impoverished local soils.

Keywords Farmer knowledge $\cdot$ Fertilizer response trials · Perceptions $\cdot$ Soil management $\cdot$ Africa

\author{
Abbreviations \\ DAP Di-ammonium phosphate \\ IR Imidazolinone resistant \\ TSBF-CIAT Tropical Soil Biology and Fertility Institute \\ of the International Centre for Tropical \\ Agriculture
}

\section{Introduction}

Improvements in soil fertility to levels that boost food security in Africa will require substantial increases in 
fertilizer use (Bationo et al. 1998; Gruhn et al. 2000). The percentage of smallholder households using fertilizer in Africa is often below 10\% (FAO 2004; Tegemeo Institute 2006), corresponding to the wealthier families in the community, and fertilizers applications do follow specific recommendations (Ibid., also see Manyong et al. 2001). It has been argued that such limited adoption of fertilizer use is due to lack of subsidies (cf. Ellis 1992; IFDC 2003), poor market infrastructure (Crawford et al. 2003), or management-related constraints (Ellis 1992, pp. 127-128; Howard et al. 2000). There is no specific accurate formula or agreed-upon guide for fertilizer use in Africa. The design of programs to promote fertilizer use in this continent must take into account the variability of crop yields in response to fertilizers across agro-ecological zones, the types of crops grown, the sizes of local farms, and other social conditions (cf. Shalit and Binswanger 1984). Such factors vary greatly within short distances in sub-Saharan Africa (Poulton et al. 2006).

Variable fertilizer responses as an obstacle among smallholders

For mineral fertilizers to be used effectively there is need to strengthen farmers' knowledge about their potential benefits and limitations in the context of smallholder African farms. Variable responses of crops to mineral fertilizers are often observed on smallholder farms due to their spatial soil variability - a result of the inherent soillandscape variability interacting with past and present soil and crop management (e.g., Buerkert et al. 2001; Tittonell et al. 2005; Vanlauwe et al. 2005). Disparate crop responses to fertilizers caused by this variability discourage fertilizer use among smallholder farmers. Variability in the response of crops to fertilizers can also be caused by poor agronomic practices, e.g. poor seedbed preparation, narrow spacing, limited use of improved genotypes, delay in planting, incorrect fertilizer placement, or weed and pest problems (Tittonell et al. 2007). Many of these problems result from poor labor availability (e.g., Place et al. 2003). Although different organic sources may be used to manage soil fertility, they are often not available in sufficient amounts to replenish nutrient stocks in already depleted soils.

Both negative fertilizer responses with respect to crop produce prices, and lack of cash in hand at planting, contribute to limited adoption of fertilizers (Abdoulaye and Sanders 2005). However, farmers need to understand that boosting plant nutrient availability does not necessarily require heavy applications of mineral fertilizer (Buresh and Giller 1998). Indeed, some degree of farmer skepticism concerning recommended rates of application may be well founded (Ibid.). Even if recommended rates were used, if local variability or other circumstances (such as lack of rain, seed quality) are not favorable, commensurate yields for increased application of fertilizer are unlikely (Poulton et al. 2006, p. 15). There is a need to clarify intricacies of fertilizer use among smallholders, such as the causes of variable crop responses, the short and long-term effects of fertilizer use on soil productivity, and the technicalities of fertilizer formulations and application rates.

The need to strengthen smallholder understanding of mineral fertilizers

Knowledge in selection of farming practices plays an important role in success of smallholder farmers (Bentley 1989). Knowledge is the most critical element of smallholder farming, more than tools or research inputs such as fertilizer (Netting 1993). Studies on smallholder farming show that "technological inventions and scientific discovery are not the crucial causal factors in the course of agricultural intensification" (Netting 1993, p. 57). It therefore follows that insufficient use of fertilizers must be tackled through strategies that enhance knowledge and counter negative or inaccurate perceptions. Improving farmers' understanding is an essential element in the development and application of integrated soil fertility management (ISFM) technologies (Deugd et al. 1998). For instance, Bannister and Nair (2003) show the role of knowledge in selection and allocation of trees according to soil fertility levels. For this to be achieved, effective knowledge use strategies must be situated in the respective smallholder context (Fujisaka 1989; Farouque and Tekeya 2008). Participatory experimentation is an important element in site-specific learning (Defoer et al. 2000). It is widely recognized that hands-on learning is highly effective for enhancing farmers' understanding of agricultural technologies (Onduru et al. 2001; De Jager et al. 2004; Ramisch et al. 2006; Hoffmann et al. 2007). It assists smallholders to apply technologies successfully in their specific local conditions (cf. Jiggins and de Zeeuw 1992; Röling and Van de Fliert 1994; Röling and Pretty 1997.

The reality about the critical role of mineral fertilizers described above drove scientists at the Tropical Soil Biology and Fertility Institute of CIAT (TSBF-CIAT) to target improved use of fertilizer among farmers. Central to this goal was collective field experimentation, involving local farmers, to improve their knowledge and fertilizer application practices (Ramisch et al. 2006). These trials were intended to strengthen knowledge by building on farmers' particular interests, and on their capacity to observe, experiment, and interpret results of fertilizer experiments (cf. Deugd et al. 1998). These experiments were based on the understanding that knowledge is the linchpin for any intensification practices that incorporate 
the use of new technologies (cf. Netting 1993). The overall theme of these experiments was to generate and disseminate integrated principles rather than bare empirical prescriptions or technology packages, while specifically aiming to strengthen farmers' knowledge of mineral fertilizers, and to improve their management practices. It was hypothesized that practical knowledge about crop fertilizer responses would improve smallholder perceptions of mineral fertilizer. This paper reports this learning experience, with the goal of analyzing current smallholder knowledge on fertilizer and nutrient management and drawing methodological lessons from the collective fertilizer-response experiments.

\section{Study objective}

The specific objective of this study was to examine smallholder knowledge about, and perceptions of, fertilizers following interactive learning trials. This study first presents the process and outcomes of collective experimentation. These trials began with the goal of clarifying crop nutrient responses through fertilizer application to improve smallholder knowledge of the fertilizer-yield phenomenon. Through focus group discussions and indepth interviews, we collected data on how participating farmers interpreted the trial outcomes and results, and this paper analyzes patterns of perceptions that emerged.

\section{Materials and methods}

\section{Study sites}

Participating farmers originated from several villages of Emuhaya Division, Vihiga District; Chakol Division, Teso District, all in western Kenya. The sites were purposively selected to follow up previous TSBF-CIAT research done under the Folk Ecology (FE) participatory learning initiative. Western Kenya comprises highland and midland agroecological zones that receive 1,200-2,100 $\mathrm{mm}$ of annual rainfall in a bimodal pattern (Jaetzold and Schmidt 1982). In typical years, $60-70 \%$ of the rainfall occurs during the "long rain" season, between February and June, while the rest falls during the "short rains" period between August and November. Farms sizes are small (0.5-2 ha), and although soil types vary within the landscape, soils are considered to be general fertile, for example, $70 \%$ of the area is considered to be of high agricultural potential). In general, current soil fertility is poor as a result of continuous cultivation with little nutrient input through organic and/or mineral fertilizers, a state which has been aggravated by soil erosion by water. Crop productivity in the region is mostly limited by the nutrients $\mathrm{N}$ and $\mathrm{P}$; localized potassium (K) deficiencies have were also been reported (Bationo et al. 1998). This results in average yields of maize (Zea mays L.), the main staple crop in the region, of $1 \mathrm{t} / \mathrm{ha}^{-1}$. Other crops grown in the region include common bean (Phaseolus vulgaris L.) and cassava (Manihot esculenta Crantz), sorghum (Sorghum bicolor (L.) Moench), sweet potato (Ipomoea batatas (L.) Poir.), cowpea (Vigna unguiculata (L.) Walp.), finger millet (Eleusine coracana (L.) Gaertn. ssp. africana), sugar cane (Saccharum officinarum L.) and banana (Musa spp. L.; Acland 1971; Tittonell et al. 2005). The soils of the study villages in Emuhaya are ferralo-orthic Acrisols, with slopes between 5 and $16 \%$, and receive between 1,800 and $2,000 \mathrm{~mm}$ of precipitation. The experimental farm was located $1,556 \mathrm{~m}$ above sea level. In Chakol Division, soils can be generally characterized as dystric and humic Cambisols, with a fairly flat landscape (slopes $\ll 5 \%$ ), and receiving between 1,270 and $1,500 \mathrm{~mm}$ of rain annually. The experimental farm was located $1,225 \mathrm{~m}$ above sea level.

The history of farming in western Kenya is characterised by low input-low output farming. The low use of appropriate soil fertility management technologies and generally poor practices mean that nutrient balances are seriously deficient (Stoorvogel and Smaling 1990). This study targeted the smallholders, who formed about $90 \%$ of the population of study areas, an area with food deficiency occurring among $89.5 \%$ of the population (Wangila et al. 1999). Poverty is a defining characteristic of western Kenya, with an average of more than $60 \%$ of the population living on less than a dollar a day (FAO 2004). Agricultural production in western Kenya is vulnerable to many outside factors, including a difficult policy environment, poor access to markets, low prices, high input costs, and higher incidences of crop and human diseases (including HIV/AIDS and malaria; Misiko 2007).

\section{Fertilizer-response collective trials}

Collective trials were established to guide smallholder farmers on correct use of mineral nitrogen $(\mathrm{N})$ and phosphorus $(\mathrm{P})$ fertilizers. The experiments served to analyze crop responses to incremental applications of these nutrients alone and in combination. Previous nutrient allocation research (e.g. Vanlauwe et al. 2002) and participatory assessments involving farmers (TSBF 2001) pointed to $P$ being the most limiting nutrient for crop production in Emuhaya, and to $\mathrm{N}$ being the most limiting in Chakol. Considering this, and to avoid a complex and potentially confusing experimental design, the learning trials consisted of maize plots receiving increasing rates of $\mathrm{P}$ in Emuhaya and of $\mathrm{N}$ in Chakol. The design was then backed up with exchange visits between the sites. Farmers identified host fields on the basis of proximity to their homesteads, the 
popularity of the host farmer, and the need to ensure that fields selected for the experiments had soils representative of each locality. Composite samples taken from the fields on adjacent trial plots were air-dried, ground and sieved through $2 \mathrm{~mm}$ and analyzed for soil organic carbon (C) C, total $\mathrm{N}$, extractable $\mathrm{P}$ and $\mathrm{K}$, and $\mathrm{pH}$ following standard methods for tropical soils (Anderson and Ingram 1993). Soils in Emuhaya had on average: organic C, $12.3 \mathrm{~g} \mathrm{~kg}^{-1}$; total $\mathrm{N}, 1.3 \mathrm{~g} \mathrm{~kg}^{-1}$; extractable $\mathrm{P}, 5.6 \mathrm{mg} \mathrm{kg}^{-1}$; and exchangeable $\mathrm{K}, 0.34 \mathrm{cmol}_{(+)} \mathrm{kg}^{-1} ; \mathrm{pH}, 5.7$. Soils in Chakol were poorer than those of Emuhaya, having on average: organic $\mathrm{C}, 4.8 \mathrm{~g} \mathrm{~kg}^{-1}$; total $\mathrm{N}, 0.5 \mathrm{~g} \mathrm{~kg}^{-1}$; extractable $\mathrm{P}, 2.6 \mathrm{mg} \mathrm{kg}^{-1}$; exchangeable $\mathrm{K}, 0.18 \mathrm{cmol}_{(+)}$ $\mathrm{kg}^{-1} ; \mathrm{pH}, 5.9$.

Maize as the test crop was planted on $6 \mathrm{~m} \times 6 \mathrm{~m}$ plots, spaced at $0.75 \times 0.25 \mathrm{~m}$ within the plots, during the first and second rainy seasons of 2003 (Fig. 1). Fertilizers were broadcast on the experimental plots during the long rainy season, using the following rates and combinations:

Chakol: $\mathrm{N}$ was applied at rates of $0,45,90,135$, and $180 \mathrm{~kg} \mathrm{~N} \mathrm{ha}^{-1}$, with and without simultaneous application of $60 \mathrm{~kg} \mathrm{P} \mathrm{ha}^{-1}$, totaling 10 experimental units (Fig. 1a).

Emuhaya: $\mathrm{P}$ was applied at rates of 0, 30, 60, 90 and $120 \mathrm{~kg} \mathrm{P} \mathrm{ha}{ }^{-1}$, with and without simultaneous application of $60 \mathrm{~kg} \mathrm{~N} \mathrm{ha}^{-1}$, totaling 10 experimental units (Fig. 1b).

There was $1 \mathrm{~m}$ space between rows with and without fertilizers, and $0.5 \mathrm{~m}$ separating plots that received different $\mathrm{N}$ or $\mathrm{P}$ rates.

There was only a single replicate of each treatment, because having many replicate plots per site proved

(a)

\begin{tabular}{|c|c|c|c|c|}
\hline $\begin{array}{c}0 \mathrm{~kg} \mathrm{~N} \mathrm{ha}^{-1} \\
(-\mathrm{P})\end{array}$ & $\begin{array}{c}45 \mathrm{~kg} \mathrm{~N} \mathrm{ha}^{-1} \\
(-\mathrm{P})\end{array}$ & $\begin{array}{c}90 \mathrm{~kg} \mathrm{~N} \mathrm{ha}^{-1} \\
(-\mathrm{P})\end{array}$ & $\begin{array}{c}135 \mathrm{~kg} \mathrm{~N} \mathrm{ha}^{-1} \\
(-\mathrm{P})\end{array}$ & $\begin{array}{l}180 \mathrm{~kg} \mathrm{~N} \mathrm{ha}^{-1} \\
\text { (-P) }\end{array}$ \\
\hline \multicolumn{5}{|c|}{$\downarrow 1 \mathrm{~m}$} \\
\hline $\begin{array}{l}0 \mathrm{~kg} \mathrm{~N} \mathrm{ha}^{-1} \\
(+\mathrm{P})\end{array}$ & $\begin{array}{c}45 \mathrm{~kg} \mathrm{~N} \mathrm{ha}^{-1} \\
(+\mathrm{P})\end{array}$ & $\begin{array}{l}90 \mathrm{~kg} \mathrm{~N} \mathrm{ha}^{-1} \\
\quad(+\mathrm{P})\end{array}$ & $\begin{array}{c}135 \mathrm{~kg} \mathrm{~N} \mathrm{ha}^{-1} \\
(+\mathrm{P})\end{array}$ & $\begin{array}{l}180 \mathrm{~kg} \mathrm{~N} \mathrm{ha}^{-1} \\
\quad(+\mathrm{P})\end{array}$ \\
\hline
\end{tabular}

(b)

\begin{tabular}{|c|c|c|c|c|}
\hline $\begin{array}{c}0 \mathrm{~kg} \mathrm{Pha}^{-1} \\
(-\mathrm{N})\end{array}$ & $\begin{array}{c}30 \mathrm{~kg} \mathrm{Pha}^{-1} \\
(-\mathrm{N})\end{array}$ & $\begin{array}{c}60 \mathrm{~kg} \mathrm{P} \mathrm{ha}^{-1} \\
(-\mathrm{N})\end{array}$ & $\begin{array}{c}90 \mathrm{~kg} \mathrm{P} \mathrm{ha}^{-1} \\
(-\mathrm{N})\end{array}$ & $\begin{array}{c}120 \mathrm{~kg} \mathrm{P} \mathrm{ha}^{-1} \\
(-\mathrm{N})\end{array}$ \\
\hline $\begin{array}{c}0 \mathrm{~kg} \mathrm{Pha}^{-1} \\
(+\mathrm{N})\end{array}$ & $\begin{array}{c}30 \mathrm{~kg} \mathrm{Pha}^{-1} \\
(+\mathrm{N})\end{array}$ & $\begin{array}{c}60 \mathrm{~kg} \mathrm{Pha}^{-1} \\
(+\mathrm{N})\end{array}$ & $\begin{array}{c}90 \mathrm{~kg} \mathrm{Pha}^{-1} \\
(+\mathrm{N})\end{array}$ & $\begin{array}{c}120 \mathrm{~kg} \mathrm{Pha}^{-1} \\
(+\mathrm{N})\end{array}$ \\
\hline
\end{tabular}

Fig. 1 Layout of the trial plots in Emuhaya and Chakol Divisions, western Kenya: a response to incremental $\mathrm{N}$ application rates with and without $\mathrm{P}$ (at $60 \mathrm{~kg} \mathrm{ha}^{-1}$ ); b response to incremental $\mathrm{P}$ application rates, with and without $\mathrm{N}$ (at $60 \mathrm{~kg} \mathrm{ha}^{-1}$ ) confusing to farmers during a previous exercise in 2002, and because these were not the only trials present on the experimental farms (TSBF 2001). It was not easy to get sufficiently large areas of adequate land protected from theft or grazing and easily accessible to all farmers. Maize was planted on the two learning trials on April 3, 2003, and harvested on August 13, 2003. Yields for harvested plots were weighed with farmers present at the plots, and then taken to the TSBF laboratories for oven-drying and weighing. Maize grain yields were assessed jointly with farmers, as part of the participatory monitoring and evaluation process. Possible causes of fertilizer responses were identified and analyzed together with farmers.

The residual fertility on plots where response to $\mathrm{N}$ and $\mathrm{P}$ had been tested was evaluated on maize without fertilizers in the second season (planted September 10, 2003 and harvested on January 14, 2004). Unfortunately, although the participating farmers had the opportunity to follow the progress of the complete trial from planting to physiological maturity of maize, biophysical data (i.e. final dry matter yields) could not be collected from the residual fertility plots at Chakol due to premature harvesting by unknown persons.

These experiments were collectively run by farmers and scientists. Farmers were organized as farmer field schools and research groups were wholly responsible for deciding on the location of the collective trials. Farmers selected "problem soils" (udongo tatanishi, Swahili) to establish the trials, including (inter alia) selection of heavily depleted sites or those heavily infested with parasitic Striga weeds. Farmers participated in the collection and analysis of information from the trial, and in the subsequent discussion sessions aimed at generating lessons. Visits to experimental sites were also paid for by farmers on their own initiative to carry out independent evaluation, free from researcher influence.

Focus group discussions and in-depth interviews

Notes taken by farmers and researchers on the experiments were usually collectively analyzed in open forums at the trials. However, detailed analysis of data was done in eight focus group discussions consisting of 12-17 regular participants. Participants were diverse; women and men farmers selected from local farmer field schools and research groups that managed the experiments. Only participants in the trials were selected in order to gauge understand the influence of the fertilizer trial. These discussions further covered farmer's experiences with fertilizer on their individual farms. Results from these discussions were therefore focused, intended for in-depth understanding of smallholder experiences, rather than producing generalizable information such as cost or labor constraints on fertilizer use. 
Individuals from forty households were interviewed during the second rainy season (short rains) of 2005 to document their own "try outs" related to the fertilizer trials; i.e., motivated by the collective trials, farmers that consistently participated in these activities established their own, spontaneous forms of experimentation with fertilizers on their farms. Participant observation was used in these cases to learn more about farmer expertise as applied to fertilizer try-outs and everyday practice. The research was here interested in emic perspectives (i.e. locally shaped insider understandings) of mineral fertilizers following the trials. As a tool, participant observation works best in longterm enquiries, and is best suited to in-depth understanding of processes on a few farms.

Focus group discussions and in-depth interviews were focused on four main themes: (a) what the farmer learned from the collective trials; (b) how fertilizer was defined, and their perceptions; (c) selection of fertilizers for specific applications or in response to specific constraints; and (d) actual fertilizer use. Narratives and practices were documented as part of the in-depth data collection on fertilizer knowledge (and perceptions). Analyzes of data from focus group discussions were done with farmers. Interview guides were used to generate in-depth data according to categories that were content-analyzed with reference to participant observation data sets. Frequency counts and comparison analyses were carried out on all data from informants.

\section{Results}

Response to fertilizer in the collective trials

The collective trials at Emuhaya revealed that the application of $\mathrm{N}$ or $\mathrm{P}$ alone was insufficient to enhance yield of maize during the long rains (Fig. 2a). Plots receiving $30 \mathrm{~kg}$ $\mathrm{P} \mathrm{ha}^{-1}$ without $\mathrm{N}$ and $60 \mathrm{~kg} \mathrm{~N}^{-1}$ without $\mathrm{P}$ produced more than double grain yields when compared with control plots without $\mathrm{P}$ and $\mathrm{N}$, yet grain yields remained below $2 \mathrm{tha}^{-1}$ in all fertilized plots. Higher rates of $\mathrm{P}$ application without $\mathrm{N}$ led to poorer yields than the control without fertilizers. When $60 \mathrm{~kg} \mathrm{~N}^{-1}$ was applied together with $\mathrm{P}$, yields increased, and continued to increase up to application rates of $60 \mathrm{~kg} \mathrm{P} \mathrm{ha}^{-1}$ (up to ca. $3 \mathrm{t} \mathrm{ha}^{-1}$ ); further yield increase was recorded for higher $\mathrm{P}$ rates. The response to $\mathrm{P}$-alone on the trial plots was highly influenced by the incidence of the parasitic Striga weed and by spatial variability in the background soil fertility of the experimental plots. There was no residual effect of $\mathrm{P}$ fertilizers on maize yields in the short rains (Fig. 2b). This subsequent crop helped illustrate the interaction between $\mathrm{N}$ and $\mathrm{P}$; although crops often benefit from the residual

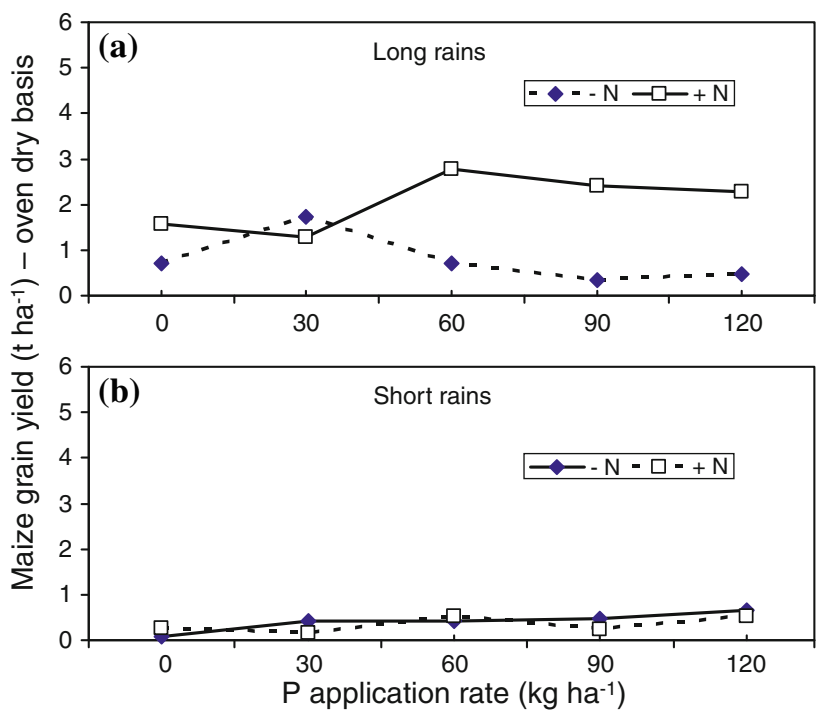

Fig. 2 Maize grain yield response to increasing rates of $\mathrm{P}$ applied as triple super phosphate with, or without $\mathrm{N}$ added at the rate of $60 \mathrm{~kg} \mathrm{ha}^{-1}: \mathbf{a}$ in the season of application (long rains) and $\mathbf{b}$ in the subsequent season (short rains) when no additional $\mathrm{N}$ fertilizer was added i.e. residual effect of $\mathrm{N}$ and $\mathrm{P}$ combined, in Emuhaya

fertility of $\mathrm{P}$ applied in a previous season, the grain yield of maize was very low at all rates of $\mathrm{P}$ because of $\mathrm{N}$ was limiting-clear $\mathrm{N}$ deficiency symptoms were observed in the field. $\mathrm{N}$ is more mobile in the soil and prone to losses by leaching between seasons, so is less likely to carry over from a previous season than $P$.

The interaction of $\mathrm{P}$ and $\mathrm{N}$ was clearer in the trial plots for incremental response to $\mathrm{N}$ in Chakol, where the maximum yields achieved were much larger than those normally obtained by farmers (Fig. 3). The application of $\mathrm{N}$ at increasing rates without $\mathrm{P}$ led to an almost linear yield response, resulting in grain yields of $>4 \mathrm{tha}^{-1}$ (i.e., 4 times more than in the control plots) when $180 \mathrm{~kg} \mathrm{~N} \mathrm{ha}^{-1}$ was applied. The incremental application of $\mathrm{N}$ together with $60 \mathrm{~kg} \mathrm{P} \mathrm{ha}^{-1}$ led to a steeper yield response, up to application rates of $90 \mathrm{~kg} \mathrm{~N} \mathrm{ha}^{-1}$, when no further yield increases occurred even at higher $\mathrm{N}$ rates. The application of $60 \mathrm{~kg} \mathrm{P} \mathrm{ha}{ }^{-1}$ when no $\mathrm{N}$ was applied did not improve yields with respect to the control plots without $\mathrm{N}$ and $\mathrm{P}$.

Farmers' understanding and lessons

from the experiment

Interviews revealed that practically all farmers involved in the collective trials had done some basic fertilizer experiments on their own farms during the long rains period of 2004 and 2005. Farmers planted maize (and soybean in some cases) and compared overall crop performance with and without fertilizer, between types of fertilizers, or responses of same fertilization schemes on different types 


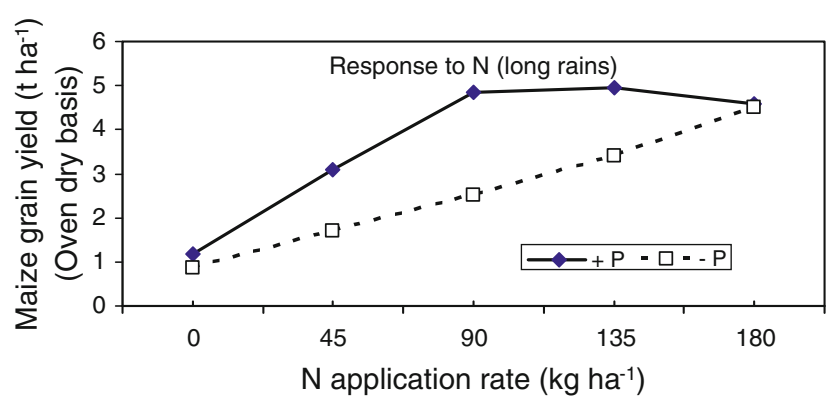

Fig. 3 Maize grain yield response to increasing rates of $\mathrm{N}$ applied as urea with, or without $\mathrm{P}$ added at the rate of $60 \mathrm{~kg} \mathrm{ha}^{-1}\left(\right.$ as $\mathrm{P}_{2} \mathrm{O}_{5}$ ), in Chakol. Residual experiment was destroyed

of soils. The objective was to evaluate response through performance, and to increase yield. Many of these try-outs were also learn-as-you-go experiments. Comparisons between different responses were made over more than one season in many cases, and so farmers relied on memory to draw conclusions. In spite of this lack of standardized or systematic application of experimental procedures, some trends were apparent. The majority ( 30 of 40 ) of the learn-asyou-use processes included combinations or comparisons with the commonly used farm yard manure. Nonetheless, procedures used and amounts applied by farmers did not allow for broad learning or the generation of new knowledge on fertilizers, and did little to improve negative perceptions of the value of application of mineral fertilizers.

Results of the farmer focus group discussions indicated that farmers analyzed soils and fertilizer use, by analogy, in human terms. In Emuhaya for instance, participants suggested that the same way humans become accustomed to fried foods, soils can get addicted to mineral fertilizer; "once used, always to be used." If one stops, maize yields were anticipated to plummet badly compared with yields obtained on soils that had not received regular fertilizer applications. This analogy appeared to be confirmed in the minds of farmers based on the poor maize yields observed on the experiments conducted during the second season (growing on the residual fertility-cf. Fig. 2b). It was the drastic drop that was so noticeable, more than the general productivity of the farm. Perceptions of fertilizers as causal in producing addiction or polluting the soil were common, and only verified during the collective fertilizer response experiment. This pattern of thinking among farmers must also be seen against the backdrop of many non-governmental organizations working in these areas. Promotion of what farmers quoted as "clean farming" seems to influencing some of the poor smallholders who have similar experiences and who cannot consistently afford enough fertilizer-yet do not have access to adequate amounts of, or high quality, organic inputs. There was also a general perception of mineral fertilizer as being a replacement for organic manures. This understanding conflicted with the recommendation of combined applications of mineral and organic fertilizers that TSBF-CIAT has proclaimed in the region.

The results from the focus group discussions also showed that soil fertility was defined as richness of the soil, and not merely as nutrient availability. Among the Luyiaspeakers of Emuhaya, fertility was referred to as obunulu, meaning "fatty" or "sated." When soil was sated, it had mabole (i.e., decomposed resources). The Ateso of Chakol referred to this as abosetait. Mabole or abosetait are generic terms, denoting dark color, richness of resources, etc., and referred to more than soil nutrients. Fertilizers were instead commonly referred to in Swahili (not the indigenous vernacular, as mbolea ya duka (fertilizer from the shop) or mbolea ya kizungu (white man's fertilizer). Since fertilizer was not included within the concepts of abosetait or obunulu in the broadest sense, five elderly informants believed fertilizers had "spoiled" the soil and reduced earthworms (ekaeret, Chakol; emiambo/milambo, elsewhere) on the experimental plots. These informants insisted that continued use or over-use of fertilizers on the experimental plots would result in soil addiction because it would limit the abundance of soil fauna. A common analogy presented after the trial related to the residual value of fertilizers. Mineral fertilizer was likened to sugar. It was viewed as a quick-fix addition which "replenishes lost energy almost instantly, but does not remain in the 'body' [soil] for long."

The foregoing account shows something of the way mineral fertilizers were viewed as embedded in history, beyond the farmers' experiences on the collective experiment. Although these long term perceptions continue to shape the nature of fertilizer use, new analogies became crucial in aiding interactions between farmers and scientists. Participants also coined farmer-friendly names for nitrogen and phosphorus. $\mathrm{N}$ became Jeni, and $\mathrm{P}$ was referred to as Fosi. Potassium (K) was referred to in Swahili as Kali. These were easier to remember, and even their roles became clearer to perceive. Besides being highly needed by crops, they are complementary. Local soils were explained as soils which lacked both Fosi and Jeni, and so the soils were "unhealthy". Because both may be accessible only to a limited extent, combining them is better. One also needs to know the respective "symptoms" of an unhealthy soil due to lack of Fosi and Jeni, among other things, so as to "identify the right treatment." Farmers were also informed that nutrients coming either from mineral fertilizer or from organic manure are the same to the plant. 
Perceptions on factors deterring fertilizer use

All 40 informants experienced or considered crop response as important information affecting the way they viewed fertilizers. Yields were poor at lower fertilizer rates (cf. Figs. 2 and 3), confirming the familiar outcome among the local farmers who apply very low doses of fertilizer. Thirty informants said that over the last 10 years they had experienced lack of clear yield improvement or "ambiguous responses," i.e., uncertain yield responses when they used mineral fertilizer on the "infertile" sections of their farms where it was most needed. They commonly described such poor yields as "soul-breaking" (i.e., maven ilivunja roho). Although the collective trial was meant to improve understanding on fertilizer response, farmers expected researchers to solve ambiguity. Usually ambiguity was blamed on "fertilizers of nowadays" (mbolea za siku hizi, i.e., fake or adulterated fertilizers), bad seed, rain failure, disease' in the soil, or even witchcraft. The all too common frustration with depleted soils meant that fertilizers were targeted to plots where "results would at least be assured" (focus group discussion, Emuhaya, March, 2005). Another correlation between farmers' experiences and those of the collective trials was that fertilizer was not applied during the second season. This lack of consistent fertilizer application in the poor soils was perceived as resulting in no or low residual build-up of soil fertility, as witnessed on the collective experiment.

Farmers' experiences with yields from their plots corresponded to data produced by the collective trials, which underscored the resistant nature of heavily depleted local soils. These, along with complex historical built-in knowledge that farmers had on fertilizer were largely responsible for the patterns of nutrient resource allocations that we observed in the fields of western Kenya. These led, over time, to soil fertility gradients (see Tittonell et al. 2005; Vanlauwe et al. 2005 for description) i.e., reinvesting the little nutrient input they obtained on the fields where they expected a higher responses, while cropping other depleted sections without the use of fertilizer.

The rates of fertilizer used on the collective trials were higher than what farmers ordinarily used (e.g., compare with Bekunda et al. 2004; Tegemeo Institute 2006). The fact that higher rates resulted in better yields did not therefore gain currency as a practical lesson for the vast majority of participants. Higher rates also meant greater cost per unit of application. In all focus group discussions and during in-depth interviews, farmers ranked cost as the most important deterrent to the use of mineral fertilizers. All the forty informants said they experienced difficulty buying fertilizers. Only five of the forty farmers interviewed bought a $50 \mathrm{~kg}$ bag of fertilizer in 2004. In particular, 10 informants said that a worsening fertilizer-maize price ratio had resulted in reduction of application rates. Falling or negative net gains for existing cash crops, which received more mineral fertilizer than maize, had a negative effect on purchase of fertilizers. Fifteen informants who had used fertilizer during the long rains stated that they would not contemplate do so again during the short rains, regardless of whether the results. On the other hand, all informants used manures during the short rains period of 2004 following participation in the collective experiments. The general perception was that farmyard manure was cheaper, local, a known quantity, and it did not tie up significant funds all at one time. However, quality and amounts of manure available were limited. Therefore, separate collective experiments were subsequently organized to assist farmers to experiment with the combined used of mineral fertilizer and organic manures.

Good yield responses to fertilizers also depend on the crop germplasm or variety used. The imidazolinone resistant (IR) maize that was used in the experiment, and touted by researchers as resistant to Striga, came under scrutiny. Farmers observed that these IR varieties did not in fact perform better than typically used hybrids or even local varieties (believed by scientists to be less responsive to fertilizer use). The seed coating meant to kill germinating Striga plant, may in fact have been washed off due to heavy rains at the time of planting. Farmers observed that "maize performance on the learning trials compared unfavorably with adjacent farms." As a result, none of the 40 farmers interviewed purchased this IR maize variety in subsequent seasons. Farmers instead suggested that it would be helpful to do an experiment on effective Striga control and fertilizer response with different maize varieties as the treatment. Following the collective experiment, however, it appeared that farmers (25 of 40) linked Striga prevalence to increased use of mineral fertilizer. These farmers believed that farmyard manure, and not mineral fertilizer, could be used to prevent or inhibit Striga prevalence.

Perceptions shaping decisions on choice and allocation of fertilizers

Fifteen informants said they had used mineral fertilizer (mavuno or di-ammonium phosphate, DAP) following the collective experiments. However, the majority of informants (35/40) did not have clear knowledge about the nutrient contents of the different fertilizers available on local markets, even after participating in the collective experiments. Farmers still based their decisions on common fertilizer distinctions such as: (1) the "dark one" or one "used by researchers"; (2) "the one given to tea farmers"; (3) the "salty one" that scorches easily; (4) the "whitish one" for top dressing, or (5) the "grey one" for 
planting. All informants identified DAP as "for planting." Therefore, it was considered to be different from calcium ammonium nitrate and urea used for top dressing maize, but no informant had ever used triple super-phosphate (TSP), which is commonly used by researchers. Fertilizers were not therefore known in terms of their nutrient values, which hindered their success and learning from farmers' own try outs. In any case, soil nutrient deficiencies were assigned different interpretations, e.g., the "dangerous disease" was assigned to the occurrence of purple coloration in maize leave, which scientists usually consider to be a common symptom of $\mathrm{P}$ deficiency. Farmers therefore needed information on diagnosing deficiencies or problems with crops through soil nutrient test strips, and to understand the concept of the "limiting factor" when key soil nutrients are deficient (e.g.,. whether $\mathrm{N}$ or $\mathrm{P}$ ) to be able to make useful conclusions from experiments. The current collective trials on fertilizer response were therefore limited in scope.

Farmer practices revealed that fertilizer applications were more often targeted for use on maize and common bean than any other crops. When quantities of fertilizers available were inadequate, plots considered more fertile and more likely to produce better harvests received high priority. Whenever informants used DAP they also applied farmyard manure or compost when planting maize (40 out of 40). By contrast, only DAP was used when planting soybeans. During all focus group discussions, participants pointed out that it was not worth using fertilizer on certain crops. Although there were clearer cases of when $P$ should be used (e.g., the obvious differences between $+\mathrm{P}$ and $-\mathrm{P}$ rows), groundnut plots in the cereal-legume trials did not clearly reveal such differences. This lent credence to a farmer point of view that mineral fertilizer was less necessary when planting groundnut, and also to some extent of little value to cassava, millet, and indigenous vegetables. These crops were also believed to add fertility to the soil.

The history of fertilizer promotion in the area played an important role in sustaining farmer perceptions after the experiment. Since colonial times, maize hybrids have usually been promoted concurrently with mineral fertilizers. As a result, not only did farmers closely associate maize hybrids with mineral fertilizers, but also inevitably with the expenses associated with this technology. If one has to buy fertilizer, then one has to also purchase hybrid seed. The experiment seems to have confirmed into logic. Fertilizer packages generally included recommendations on a per hectare basis, while instructions for use were still widely unknown to farmers (38 out of 40 ). The package and information supplied with it are mainly suitable for large-scale farmers. Focus group discussion showed the need for sensitivity of information targets to" (1) application per smaller areas, e.g. $10 \mathrm{~kg}$ per given square paces rather than many $\mathrm{kg}$ bags $\mathrm{ha}^{-1}$; (2) application rates for different varieties of maize; (3) use of simpler language; (4) specifying conditions of application that minimize seed burning and $\mathrm{N}$ leaching.

\section{Discussion}

Beyond single crop responses

Although the overall goal of this experiment was to analyze crop responses to different rates of fertilizer application, using maize as a test crop, issues such as weed infestation, depleted soils and spatial variability within farms soon emerged as critical. Research and extension on fertilizer must not give the impression that mineral fertilizer will be the sole or overriding determinant of yield increase. In reality, achieving yield potentials results from interactions between improved cultivar use, improved soil physical and chemical conditions, adequate rainfall, and good agronomic management practices (timely planting and weeding), including Striga control. Understanding timing of top-dressing of $\mathrm{N}$ fertilizers can also enhance fertilization without loss to leaching. It is thus more useful to promote fertilizer use when farmers adequately understand basic channels of soil nutrient loss (cf. Smaling et al. 1997). Information and knowledge must be clear and based on research evidence to avoid common myths such as "clean farming" (cf. Vanlauwe and Giller 2006). Misinterpreted messages about organic farming sometimes result in the idea that mineral fertilizer reduces incidence of earthworms or organic matter in the soil, key indicators of soil fertility for farmers. Since some of these myths circulate locally farmers need to take part in experiments designed to "test" any such fears. Research data suggest that indeed the contrary is true (Vanlauwe and Giller 2006).

An equally important issue was the fact that fertilizers are, in financial terms, beyond the reach of smallholders. The problem, however, is not merely a matter of the relative price of fertilizer and maize. It has more to do with sudden drops in prices of produce after abundant harvests. Since farmers have immediate needs such as school fees and medicine they sell maize immediately after harvest, or even when the crop is still green, for roasting. Also, although the concern with cost doubtless reflects genuine concerned, it should be noted that this study was carried out by researchers associated with TSBF. The expectation of assistance in acquiring subsidized fertilizer may have influenced farmers' responses.

Access to fertilizers can be enhanced through appropriate packaging and reducing distance to the nearest retail shops. This is being tried currently in the "Strengthening Folk Ecology Project" sites, through an initiative of 
researchers and a private agency to promote a new fertilizer called Mavuno (harvest, in Swahili). Mavuno was sold to farmers in small packages at KSh. $40 \mathrm{~kg}^{-1}$ (US $\$ 60$ cents) through outlets within the study locations. Accessibility, nonetheless, is a more complex issue than availability of outlets alone. In settlements where more than $50 \%$ of the farming population lives on less than US $\$ 1$ a day, few small-holders prioritized buying fertilizer during the second season of 2004.

\section{Did collective trials improve farmer perceptions?}

The hypothesis that practical knowledge improves smallholder perceptions of the value of mineral fertilizers was confirmed through this study. The experiment guided farmers toward understanding that response of crops to mineral fertilizers was more about soil properties, seed quality, weeds, and other technologies, i.e., organic inputs. The overall conclusion for the hypothesis is that the scope of the experiments was too limited compared with the breadth and depth of knowledge required to reverse local perceptions. When the collective experiments clarified the use of mineral fertilizer, farmers' perceptions improved. On-farm collective trials gave variable responses that highlighted the interactions of crop response to nutrients with weed flora and aspects of agronomic management. Thus learning trials increased awareness among farmers about challenges of fertilizer use and soil fertility experimentation, especially in a highly variable site (cf. Howeler et al. 2004). However, in the (man) cases, the scant improvements reported for certain fertilizer response experiments seemed to confirm older and deeply held perceptions - such as the link with hybrid maize. Some prior perceptions remained the same or were strengthened.

\section{Widening the approach}

Fertilizers were introduced to solve the problem of poor harvests (c.f. Newbould 1989). In reality, successful application of biological (e.g., legume) or organic technologies necessitated the use of mineral $\mathrm{P}$ fertilizer applications. In smallholder systems of western Kenya, compost and farmyard manure are available in small quantities and are low in quality with respect to nutrients. Their use does not therefore eliminate the need for mineral $\mathrm{N}$ (c.f., IFPRI 1996; Muriithi and Irungu 2004; Khaliq et al. 2006). It is also true that the application of mineral fertilizer in fields with low soil organic carbon can result in the strengthening of negative smallholder perceptions due to initial poor crop response. The application of organic resources or legumes without mineral fertilizer will not adequately improve $\mathrm{N}$ or $\mathrm{P}$ supply in the highly depleted soils of western Kenya (Fig. 4).

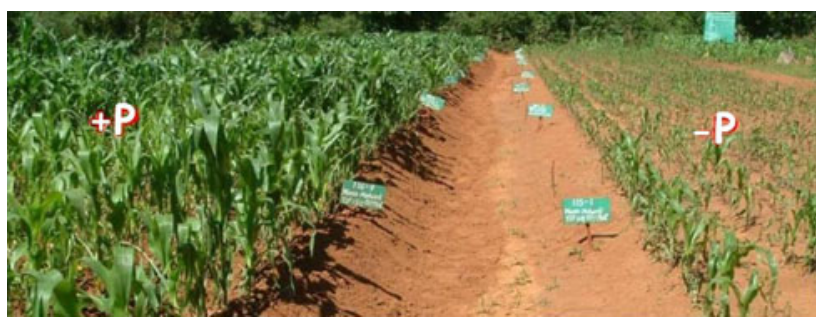

Fig. 4 Cereal-legume rotation participatory experiment (by TSBF Institute in Butula, western Kenya). The value of mineral $\mathrm{P}$ in legume-cereal rotations is critical for better nitrogen fertilizer response, higher biomass production and sustainable grain yield (Misiko 2007)

There is need to focus attention on mode and consistency of current fertilizer use by farmers, even if the amounts are limited. Besides the collective experiments, steps to encourage consistency of use were being undertaken in these sites (Misiko 2007). The activity involved non-governmental organizations by, for example, supporting staff so that they and farmers can better interpret scientific results. Other broad mechanisms include supporting the establishment of input credit schemes with farmer groups supported by diverse TSBF partners. Registered and active group members received fertilizer and seed, and were usually expected to repay within a period of 6 months. This form of credit inadvertently promoted fertilizer application on vegetables and legumes that were sometimes sold through group networks to enhance repayments. This helped break the association of fertilizer with hybrid maize only. A similar initiative encourages access to the Mavuno compound fertilizer through packaging in $1 \mathrm{~kg}$ packages, and retailing within the study sites. Such small packages are ideal for micro-dosing on mainly for-subsistence vegetables and legumes grown on selected plots by a majority of poor farmers, especially women (Misiko 2007).

Fertilizer use intricacies may mean increased access to fertilizers (and markets) alone will neither improve fertilizer knowledge among Kenyan smallholders nor guarantee its sustainable use. Use modes have to be convenient, and farmers need better farm gate prices. Access to information, especially by women, who do more of the farm work and are therefore the main fertilizer applicators, is critical.

\section{Conclusions}

Farmers' knowledge was strengthened and perceptions improved, for instance, through the broadened awareness of factors that influenced crop response to mineral fertilizer. The collective fertilizer trials showed why adaptive soil fertility research should not be about reaching a final or universal solution, but rather should serve as a basis for 
informed decision making among smallholders. Lessons from this study show that fertilizer promotion needs to take into account the interactions between biophysical variability and social contexts that influence failures and negative perceptions in places like western Kenya. This study further concludes that farmers' perceptions are not baseless, especially those resulting from erratic crop responses. They had valid basis for initial claims, but needed more effective interactive learning and a longer period of time to clarify negative results. This calls for further in-depth studies embedded in long-lasting learning cycles. Such cycles should allow farmers to participate, experiment, and build and share their knowledge consistently through targeted learning approaches that benefits from knowledge about the heterogeneous context of smallholder farming in western Kenya. There is need for further farm-level observations over several cropping seasons, aimed at understanding patterns of practices and knowledge resulting from crop responses when small doses of fertilizer are applied in a targeted manner by poor farmers. Such studies need to stratify sampling to successfully study both women and men, and to examine the influence that school education has on fertilizer perceptions in addition to practical farmer experience. Future fertilizer efforts among smallholders should be on the search for better use of the little accessible fertilizer besides improving overall fertilizer-use efficiency. This study indeed showed that pushing for more fertilizer application may inadvertently result in more strongly held negative perceptions.

Acknowledgments Special thanks are extended to the farmers of western Kenya who actively or indirectly made this study possible. The support of the International Development Research Centre (IDRC), the Rockefeller Foundation, Wageningen University and TSBF is also acknowledged. The European Union is thanked for its support of the AfricaNuances initiative.

Open Access This article is distributed under the terms of the Creative Commons Attribution Noncommercial License which permits any noncommercial use, distribution, and reproduction in any medium, provided the original author(s) and source are credited.

\section{References}

Abdoulaye, T., and J.H. Sanders. 2005. Stages and determinants of fertilizer use in semiarid African agriculture: The Niger experience. Agricultural Economics 32(2): 167-179.

Acland, J.D. 1971. East African crops: An introduction to the production of field and plantation crops in Kenya, Tanzania and Uganda. London: Longman.

Anderson, J.M., and J.S.I. Ingram. 1993. Tropical soil biology and fertility: A handbook of methods, 2nd ed. Wallingford, UK: CAB International.

Bannister, M.E., and P.K.R. Nair. 2003. Agroforestry adoption in Haiti: the importance of household and farm characteristics. Agroforestry Systems 57(2): 149-157.
Bationo, A., F. Lompo, and S. Koala. 1998. Research on nutrient flows and balances in West Africa: State-of-the-art. Agriculture, Ecosystems \& Environment 71(1-3): 19-35.

Bekunda, M.A., E. Nkonya, D. Mugendi, and J.J. Msaky. 2004. Soil fertility status, management, and research in East Africa. East African Journal of Rural Development 20(1): 94-112.

Bentley, J.W. 1989. What farmers don't know can't help them: The strengths and weaknesses of indigenous technical knowledge in Honduras. Agriculture and Human Values 6(3): 25-31.

Buerkert, A., A. Bationo, and H. Piepho. 2001. Efficient phosphorus application strategies for increased crop production in subSaharan West Africa. Field Crops Research 72(1): 1-15.

Buresh, R.J., and K.E. Giller. 1998. Strategies to replenish soil fertility in African smallholder agriculture. In Soil fertility research for maize-based farming systems in Malawi and Zimbabwe, ed. S.R. Waddington, H.K. Murwira, J.D.T. Kumwenda, D. Hikwa, and F. Tagwira, 13-19. Harare, Zimbabwe: Soil Fert Net and CIMMYT-Zimbabwe.

Crawford, E., V. Kelly, T.S. Jayne, and J. Howard. 2003. Input use and market development in Sub-Saharan Africa: An overview. Food Policy 28: 277-292.

De Jager, A., D. Onduru, and C. Walaga. 2004. Facilitated learning in soil fertility management: assessing potentials of low-externalinput technologies in east African farming systems. Agricultural Systems 79(2): 205-223.

Defoer, T., A. Budelman, C. Toulmin, and S.E. Carter. 2000. Building common knowledge: Participatory learning and action research. Amsterdam, The Netherlands: Royal Tropical Institute.

Deugd, M., N. Röling, and E.M.A. Smaling. 1998. A new praxeology for integrated nutrient management, facilitating innovation with and by farmers. Agriculture, Ecosystems \& Environment 71: 271-285.

Ellis, F. 1992. Agricultural policies in developing countries. Cambridge, UK: Cambridge University Press.

FAO. 2004. Increasing fertilizer use and farmer access in subSaharan Africa. A literature review. Rome: Food and Agriculture Organization.

Farouque, G.M., and H. Tekeya. 2008. Farmers' use of integrated soil fertility and nutrient management practices for sustainable crop production: a field-level study in Bangladesh. American Journal of Agricultural and Biological Sciences 3(4): 716-723.

Fujisaka, S. 1989. The need to build upon farmer practice and knowledge: Reminders from selected upland conservation projects and policies. Agroforestry Systems 9(2): 141-153.

Gruhn, P., F. Goletti, and M. Yudelman. 2000. Integrated nutrient management, soil fertility, and sustainable agriculture: Current issues and future challenges. Washington, DC: International Food Policy Research Institute. Food, Agriculture, and the Environment Discussion Paper 32.

Hoffmann, V., K. Probst, and A. Christinck. 2007. Farmers and researchers: How can collaborative advantages be created in participatory research and technology development? Agriculture and Human Values 24: 355-368.

Howard, J., J. Jeje, V. Kelly, and D. Boughton. 2000. Comparing yields and profitability in MADER's High-and Low-Input Maize Program. 1997/98 survey results and analysis. Maputo, Mozambique: Government of Mozambique, Ministry of Agriculture and Rural Development. Research Report 39.

Howeler, R.H., W. Watananonta, W. Wongkasem, and K. Klakhaeng. 2004. Working with farmers: The challenge of achieving adoption of more sustainable cassava production practices on sloping land in Asia. Paper presented at SSWM 2004, International Conference on Innovative Practices for Sustainable Sloping Land and Watershed Management, held in Chiangmai, Thailand. Sept 5-9, 2004. 
IFDC. 2003. Input subsidies and agricultural development: Issues and options for developing and transitional economies. Muscle Shoals, AL: International Fertilizer Development Center. Paper Series P-29.

IFPRI. 1996. Policies to promote environmentally sustainable fertilizer use and supply to 2020. http://www.ifpri.org/2020/BRIEFS/ NUMBER40.HTM. Accessed June 20, 2009.

Jaetzold, R., and H. Schmidt. 1982. Farm management handbook of Kenya, vol. I-III. Nairobi, Kenya: Ministry of Agriculture (Kenya)/GTZ.

Jiggins, J., and H. de Zeeuw. 1992. Participatory technology development in practice: Process and methods. In Farming for the future, ed. C. Reijntjes, B. Haverkort, and A. Waters-Bayer, 135-162. London, UK: MacMillan and Leusden, ILEIA.

Khaliq, A., M.K. Abbasi, and T. Hussain. 2006. Effects of integrated use of organic and inorganic nutrient sources with effective microorganisms (EM) on seed cotton yield in Pakistan. Biorespource Technology 97(8): 967-972.

Manyong, V.M., K.O. Makinde, N. Sanginga, B. Vanlauwe, and J. Diels. 2001. Fertilizer use and definition of farmer domains for impactoriented research in the northern Guinea savanna of Nigeria. Nutrient Cycling in Agroecosystems 59: 129-141.

Misiko, M. 2007. Fertile ground? Soil fertility management and the African smallholder. Ph.D. Thesis, Wageningen University, Wageningen, The Netherlands.

Muriithi, L.M.M., and J.W. Irungu. 2004. Effect of integrated use of inorganic fertilizer and organic manures on bacterial wilt incidence (BWI) and tuber yield in potato production systems on hill slopes of central Kenya. Journal of Mountain Science 1(1): $81-88$

Netting, R.McC. 1993. Smallholders, householders: Farm families and the ecology of intensive, sustainable agriculture. Stanford, CA: Stanford University Press.

Newbould, P. 1989. The use of nitrogen fertilizer in agriculture. Where do we go practically and ecologically? Plant and Soil 115: 297-311.

Onduru, D., A. De Jager., G. Gachini, and J. Diop. 2001. Exploring new pathways for innovative soil fertility management in Kenya. Managing Africa's Soils No. 25. http://www.iied.org/pubs/pdfs/ 9044IIED.pdf. Accessed 31 January 2010.

Place, F., P. Hebinck, and M. Omosa. 2003. Chronic poverty in rural western Kenya: its identification and implications for agricultural development. http://www.ifpri.org/sites/default/files/publications/ rr142.pdf. Accessed May 3, 2009.

Poulton, C., J. Kydd, and A. Dorward. 2006. Increasing fertilizer use in Africa: what have we learned?. Washington, DC: The International Bank for Reconstruction and Development.

Ramisch, J.J., M. Misiko, I.E. Ekise, and J.B. Mukalama. 2006. Strengthening 'folk ecology': Community-based learning for soil fertility management, western Kenya. International Journal of Agricultural Sustainability 4(2): 154-168.

Röling, N., and J.N. Pretty. 1997. Extension's role in sustainable agricultural development. In Improving agricultural extension. A reference manual, 181-191. Rome: Food and Agriculture Organization.

Röling, N., and E. Van de Fliert. 1994. Transforming extension for sustainable agriculture: The case of integrated pest management in rice in Indonesia. Agriculture and Human Values 11(2-3): 96-108.

Shalit, H., and H. Binswanger. 1984. Fertilizer subsidies: A review of policy issues with special emphasis on Western Africa. Washington, DC: World Bank, Research Unit, Agriculture and Rural Development Department, Operational Policy Staff. November (Discussion Paper ARU No. 27).

Smaling, E.M.A., S.S. Nwanda, and B.H. Janssen. 1997. Soil fertility in Africa is at stake. In Replenishing soil fertility in Africa, eds.
R.J. Buresh, P.A. Sanchez, and F. Calhoun, 47-63. Soil Science Society of America Special Publication 51.

Stoorvogel, J., and E. Smaling. 1990. Assessment of soil nutrient depletion in sub-Saharan Africa: 1983-2000. Report No. 28, vol. 1-4, Wageningen, Netherlands: Winand Staring Centre.

Tegemeo Institute for Agricultural Development and Policy. 2006. Can the market deliver? Lessons from Kenya's rising use of fertilizer following liberalization. Policy Brief No. 7. July. Nairobi, Kenya: Tegemeo Institute for Agricultural Development and Policy.

Tittonell, P., B. Vanlauwe., N. de Ridder, and K.E. Giller. 2007. Heterogeneity of crop productivity and resource use efficiency within smallholder Kenyan farms: Soil fertility gradients or management intensity gradients? Agricultural Systems 94(2): 376-390.

Tittonell, P., B. Vanlauwe, P.A. Leffelaar, E.C. Rowe, and K.E. Giller. 2005. Exploring diversity in soil fertility management of smallholder farms in western Kenya: I. heterogeneity at region and farm scale. Agriculture, Ecosystems \& Environment 110: 149-165.

Tropical Soil Biology and Fertility Programme. 2001. Folk ecology: Report on the preliminary community studies undertaken in August-September 2001 in western Kenya. Nairobi. Kenya: TSBF-UNESCO.

Vanlauwe, B., and K.E. Giller. 2006. Popular myths around soil fertility management in sub-Saharan Africa. Agriculture, Ecosystems \& Environment 116: 34-46.

Vanlauwe, B., J. Diels, N. Sanginga, and R. Merckx (eds.). 2002. Integrated plant nutrient management in Sub-Saharan Africa. Wallingford, UK: CAB International.

Vanlauwe, B., P. Tittonell, and J. Mukalama. 2005. Within-farm soil fertility gradients affect response of maize to fertilizer application in western Kenya. Nutrient Cycling in Agroecosystems 76: 171-182.

Wangila, J., R. Rommelse, and J. deWolffe. 1999. Characterization of households in the pilot project area of western Kenya. Nairobi, Kenya: International Centre for Research in Agroforestry, Nairobi. Unpublished report.

\section{Author Biographies}

Michael Misiko is the Social Scientist at the Africa Rice Centre (AfricaRice) in Cotonou, Benin. He also worked in a similar capacity at CIAT, Nairobi, Kenya. Misiko holds a Ph.D. in Agricultural Anthropology from Wageningen University. His research is focused on development among smallholders with respect to soil fertility and seed systems.

Pablo Tittonell is a soil scientist at Centre de Coopération Internationale en Recherche Agronomique pour le Développement (CIRAD). He previously worked at the PPS, Wageningen University and at the TSBF-CIAT Institute, Nairobi, Kenya. His research focuses mainly on the spatial (farm) heterogeneity and soil fertility management. He has a Ph.D. in soil science from Wageningen University, The Netherlands.

Ken E. Giller is Professor of Plant Production Systems, Wageningen University, and formally Professor at Wye College, University of London, UK. His extensive body of work in soil microbiology (nitrogen fixation by legumes) is widely regarded. He is now using tools of systems analysis combined with interdisciplinary approaches to search for sustainable forms of intensification of agriculture in Africa. 
Paul Richards is Professor of Technology and Agrarian Development, Wageningen University, and Professor of Anthropology, University College, London. His current research areas include agro-technologies in extreme circumstances and food security and humanitarianism. He is widely known for his extensive anthropological works, including classical ones. 